\begin{tabular}{|c|c|}
\hline CRITICAL $\underset{\substack{\text { ECOSYRTERSHIP FUND } \\
\text { PARTEM }}}{\text { CRESTE }}$ & $\begin{array}{l}\text { Western Ghats } \\
\text { Special Series }\end{array}$ \\
\hline
\end{tabular}

\title{
RECORDS OF THE ENDEMIC AND THREATENED CATFISH, HEMIBAGRUS PUNCTATUS FROM THE SOUTHERN WESTERN GHATS WITH NOTES ON ITS DISTRIBUTION, ECOLOGY AND CONSERVATION STATUS
}

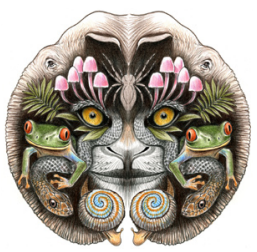

ISSN

Online 0974-7907 Print 0974-7893

OPEN ACCESS

\author{
Anvar Ali $^{1}$, Neelesh Dahanukar ${ }^{2}$, Arun Kanagavel ${ }^{3}$, Siby Philip ${ }^{4}$ \& Rajeev Raghavan ${ }^{5}$ \\ 1,3,4,5 Conservation Research Group (CRG), St. Albert's College, Kochi, Kerala 682018, India \\ ${ }^{2}$ Indian Institute of Science Education and Research (IISER), Sai Trinity, Sus Road, Pashan, Pune, Maharashtra 411021, \\ India \\ 2,5 Zoo Outreach Organization (ZOO), 96 Kumudham Nagar, Vilankurichi Road, Coimbatore, Tamil Nadu 641035, India \\ ${ }^{3}$ Wildlife Information and Liaison Development (WILD), 96, Kumudham Nagar, Vilankurichi Road, Coimbatore, Tamil \\ Nadu 641035, India \\ 17anvaraliif@gmail.com, ${ }^{2}$ n.dahanukar@iiserpune.ac.in, ${ }^{3}$ arun.kanagavel@gmail.com, ${ }^{4}$ philipsiby@gmail.com, \\ ${ }^{5}$ rajeevraq@hotmail.com (corresponding author)
}

Abstract: The Nilgiri Mystus, Hemibagrus punctatus, a rare bagrid catfish endemic to the Western Ghats, has been currently listed in the IUCN Red List, as 'Critically Endangered' with a possibility that it could be extinct. The last validated record of $H$. punctatus was known to be in 1998 , and several surveys since then have not been able to collect the species from its native range. In this paper, we provide information on new records of this rare catfish from the Western Ghats after a period of 14 years, and discuss its distribution, ecology and conservation. An updated conservation assessment of this species following the IUCN Red List Criteria is also provided.

Keywords: Bhavani, Cauvery, extinct, IUCN Red List, Nilgiri Mystus.
Jerdon (1849) described Bagrus punctatus, now included in the genus Hemibagrus Bleeker, 1862 from the River Cauvery in southern India, and suggested that the species occurs in the river and its various tributaries. The exact type locality, however, was not mentioned. Subsequently, Day $(1867,1878)$ recorded the species from the Bhavani (a tributary of the Cauvery), at the foothills of the Nilgiri Hills. Since then, very few validated records and voucher specimens of this rare catfish are

DOI: http://dx.doi.org/10.11609/JoTT.o3427.4569-78 | ZooBank: urn:Isid:zoobank.org:pub:5F7AEDCD-8A8D-4360-BB5B-6862152D0264

Editor: Carl Ferraris, Smithsonian Institution, Portland, USA.

Date of publication: 26 July 2013 (online \& print)

Manuscript details: Ms \# 03427 | Received 08 December 2012 | Final received 06 June 2013 | Finally accepted 02 July 2013

Citation: Ali, A., N. Dahanukar, A. Kanagavel, S. Philip \& R. Raghavan (2013). Records of the endemic and threatened catfish, Hemibagrus punctatus from the southern Western Ghats with notes on its distribution, ecology and conservation status. Journal of Threatened Taxa 5(11): 4569-4578; http://dx.doi.org/10.11609/ JoTT.03427.4569-78

Copyright: (c) Ali et al. 2013. Creative Commons Attribution 3.0 Unported License. JoTT allows unrestricted use of this article in any medium, reproduction and distribution by providing adequate credit to the authors and the source of publication.

Funding: Rajeev Raghavan thanks the Mohammed Bin Zayed Species Conservation Fund (MBZSCF; Project 1225670) and the North of England Zoological Society (NEZS), Chester Zoo for providing financial support for the project on the 'Lost fishes of Western Ghats'. Neelesh Dahanukar thanks the Department of Science and Technology, Government of India for the INSPIRE Faculty Fellowship.

Competing Interest: The authors declare no competing interests. Funding sources had no role in study design, data collection, results interpretation and manuscript writing.

Acknowledgements: The authors thank Brawin Kumar, Keerthi Krutha, Priyanka lyer, Payal Molur and Sanjay Molur for their encouragement and logistical support. Siby Philip thanks Allen Benziger for permission to use the photograph of Hemibagrus cf. punctatus. Rajeev Raghavan thanks Ralf Britz, The Natural History Museum (NHM), London for his help and support during the visits to the museum and in examining Day's material. The authors thank three anonymous reviewers and the subject editor for their critical comments on the manuscript.
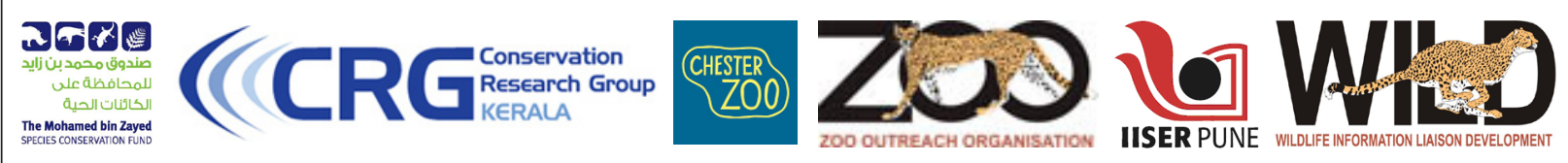

The publication of this article is supported by the Critical Ecosystem Partnership Fund (CEPF), a joint initiative of I'Agence Française de Développement, Conservation International, the European Commission, the Global Environment Facility, the Government of Japan, the MacArthur Foundation and the World Bank. 
available.

The Nilgiri Mystus or the Porthole Mystus, Hemibagrus punctatus is endemic to the Western Ghats (Dahanukar et al. 2004) where it is restricted to the tributaries and reservoirs in the Cauvery drainage ( $\mathrm{Ng} \&$ Ferraris 2000; Raghavan \& Ali 2011; Ng \& Kottelat 2013) (Fig. 1). Habitat degradation as a result of pollution, construction of dams and indiscriminate fishing were suggested to have led to drastic population declines (close to 100\%) of this species in its native range (Raghavan \& Ali 2011). Field surveys by several researchers failed to record $H$. punctatus for the last 14 years (see Raghavan \& Ali 2011). Due to the heavy declines in population, and the fact that the last confirmed sighting was in 1998, the species has been listed in the IUCN Red List of Threatened Species as 'Critically Endangered' (CR) with a possibility that it could be extinct (Raghavan \& Ali 2011).

During recent collection trips to various riverine fishing villages and reservoirs in the Cauvery basin, we came across several specimens of $H$. punctatus in the catches of local fishers. Here we document these records, and provide information on the distribution, ecology and conservation status of this rare catfish. In addition, using mitochondrial cox1 gene, we show the phylogenetic relationship of $H$. punctatus (Fig. 2) (see Appendix 1 for detailed methods).

The specimens referred to in this paper are deposited in the collections of the Wildlife Information Liaison Development Society (WILD), Coimbatore, India and the Conservation Research Group, St. Albert's College (CRGSAC), Kochi, India.

\section{Hemibagrus punctatus (Jerdon, 1849) (Images 1, 2, 3 \& 4)}

\section{Synonyms}

Bagrus punctatus Jerdon, 1849

Hemibagrus punctatus (Jerdon, 1849): Day (1867); Ng \& Ferraris (2000); Jayaram (2006); Ferraris (2007); Ng \& Kottelat (2013)

Macrones punctatus (Jerdon, 1849): Day (1877; 1889)

Aoria punctatus (Jerdon, 1849): Mukerji (1931)

Mystus (Mystus) punctatus (Jerdon, 1849): (in part) Jayaram (1954)

Mystus punctatus Jayaram (1977, 1981); Mo (1991); Talwar \& Jhingran (1991); Easa \& Shaji (2003)

Mystus menoda menoda (non Day) - (?) Barman (1993).

\section{Material examined}

Hemibagrus punctatus: WILD-12-PIS-026, 22.xi.2012, 1 male, 270mm SL, Athikadavu, Bhavani River, Tamil Nadu, India, $11.221^{\circ} \mathrm{N} \& 76.763^{\circ} \mathrm{E}$, elevation $446 \mathrm{~m}, \mathrm{R}$. Raghavan et al.; CRG-SAC-2012.12.1, 12.xii.2012, 1 male, $182 \mathrm{~mm} \mathrm{SL}$, stream $16 \mathrm{~km}$ east of Malavalli, Cauvery River, Karnataka, India, $12.403^{\circ} \mathrm{N} \& 77.199^{\circ} \mathrm{E}$, elevation 585m, A. Ali \& S. Philip; CRG-SAC-2012.12.2, 12.xii.2012, 1 male, $180 \mathrm{~mm}$ SL, Bannur, Cauvery River, Karnataka, India, $12.320^{\circ} \mathrm{N} \& 76.842^{\circ} \mathrm{E}$, elevation $644 \mathrm{~m}$, A. Ali \& S. Philip; CRG-SAC-2012.12.3, 11.xii.2012, 1 male, 232mm SL, Krishna Raja Sagar Dam, Cauvery River, Karnataka, India, $12.425^{\circ} \mathrm{N} \& 76.571^{\circ} \mathrm{E}$, elevation $748 \mathrm{~m}$, A. Ali \& S. Philip; BMNH 1868.5.14:8; 1 ex., 155mm SL, Bhavani River, India, F. Day.

\section{Morphology}

Biometric data presented in Table 1, is the first such information on fresh specimens of this rare catfish. Details of body morphology, coloration, head structure and dentition of the fresh specimen are provided in Images 1, 2 and 3 respectively. The morphometric data gathered from our specimens are largely in agreement with the data taken from museum specimens provided by Ng \& Ferraris (2000) as well as Ng \& Kottelat (2013). The small deviations in the data that are observed could

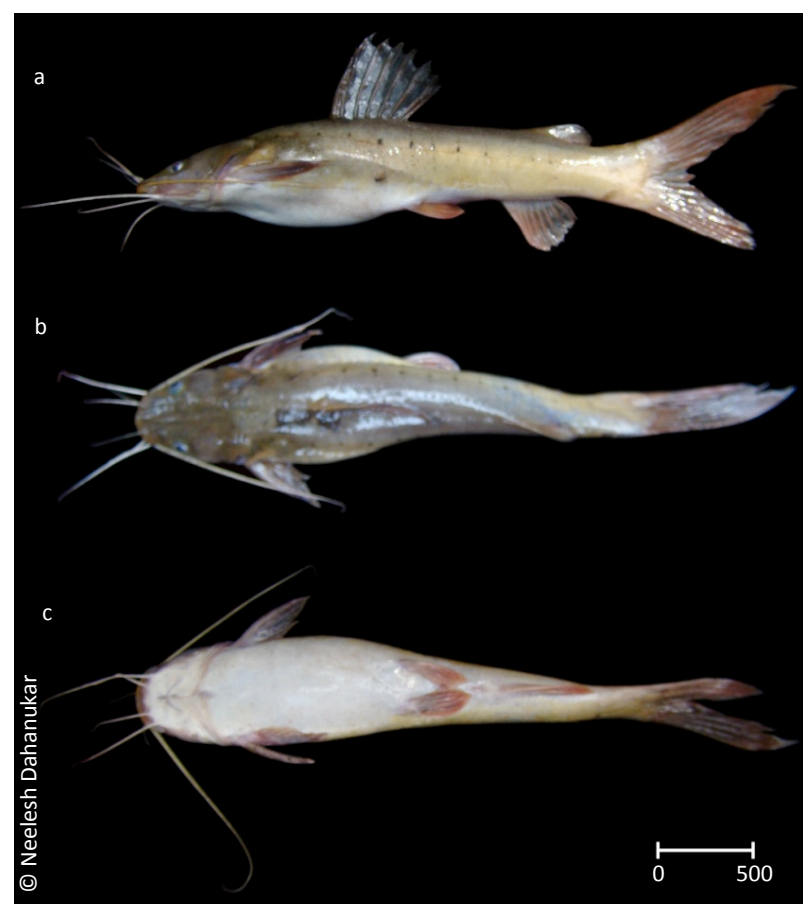

Image 1. Specimen of Hemibagrus punctatus (WILD-12-PIS-026) recorded from Bhavani River. (a) lateral, (b) dorsal and (c) ventral view. 
be due to the fact that the present measurements were taken from fresh specimens as opposed to museum specimens studied by Ng \& Ferraris (2000) and Ng \& Kottelat (2013). It is also essential to note that at least one of the specimens studied by $\mathrm{Ng} \&$ Ferraris (2000) is not in good condition (Image 5). Further, the sample size in the current and previous studies ( $\mathrm{Ng} \&$ Kottelat 2013; Ng \& Ferraris 2000) are too small ( $n=4$ and $4 / 3$ respectively).

\section{Distribution}

Hemibagrus punctatus has been recorded from Cauvery (Jerdon 1849; Rao \& Seshachar 1927; Hora 1937) and its principal tributaries, Bhavani (Day 1877; Mukerji 1931; Rajan 1955), Moyar (Rajan 1955; Rajan 1963; Manimekalan 1998), Hemavathy (Jayaram 1977; Madhyastha \& Murugan 1993) and Kabini (Easa \& Basha 1995; Shaji \& Easa 1995; Easa \& Shaji 1997). Meanwhile, Ng \& Ferraris (2000 p. 129; p. 139) gives contradicting information on the possibility of $H$. punctatus occurring in the Krishna River system. The records of this species from the Krishna drainage is by Singit et al. (1987) and Sugunan (1995) from the Tungabhadra Reservoir. With the available information, we believe that $H$. punctatus is restricted to the Cauvery River and its tributaries, and records from Krishna River including the Tungabhadra Reservoir may actually be mis-identifications. The materials from the Krishna may actually be Hemibagrus maydelli.

Although there are records of $H$. punctatus from several west flowing rivers in Kerala viz. Bharatapuzha, Chaliyar (Biju 2005) and Karuvannur (Thomas et al. 2002), they are not backed by voucher specimens and have been considered to be misidentifications (see Raghavan \& Ali 2011). However, one of the authors of the present study (SP) encountered a local fisherman near Kanjirapuzha (west flowing Bharatapuzha River Drainage) in Kerala with a catch of Hemibagrus sp.

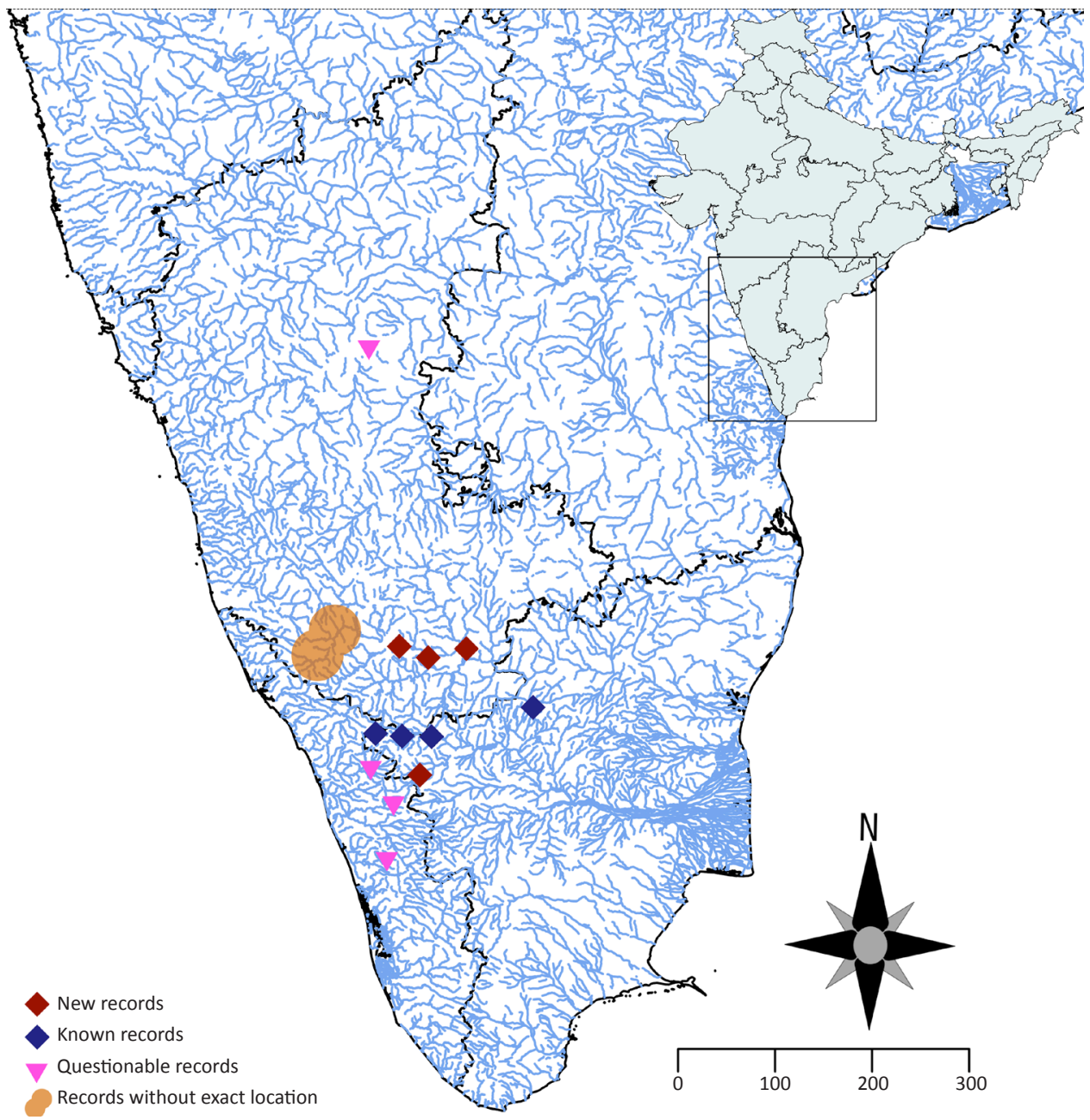

Figure 1. Distribution of Hemibagrus punctatus in peninsular India 


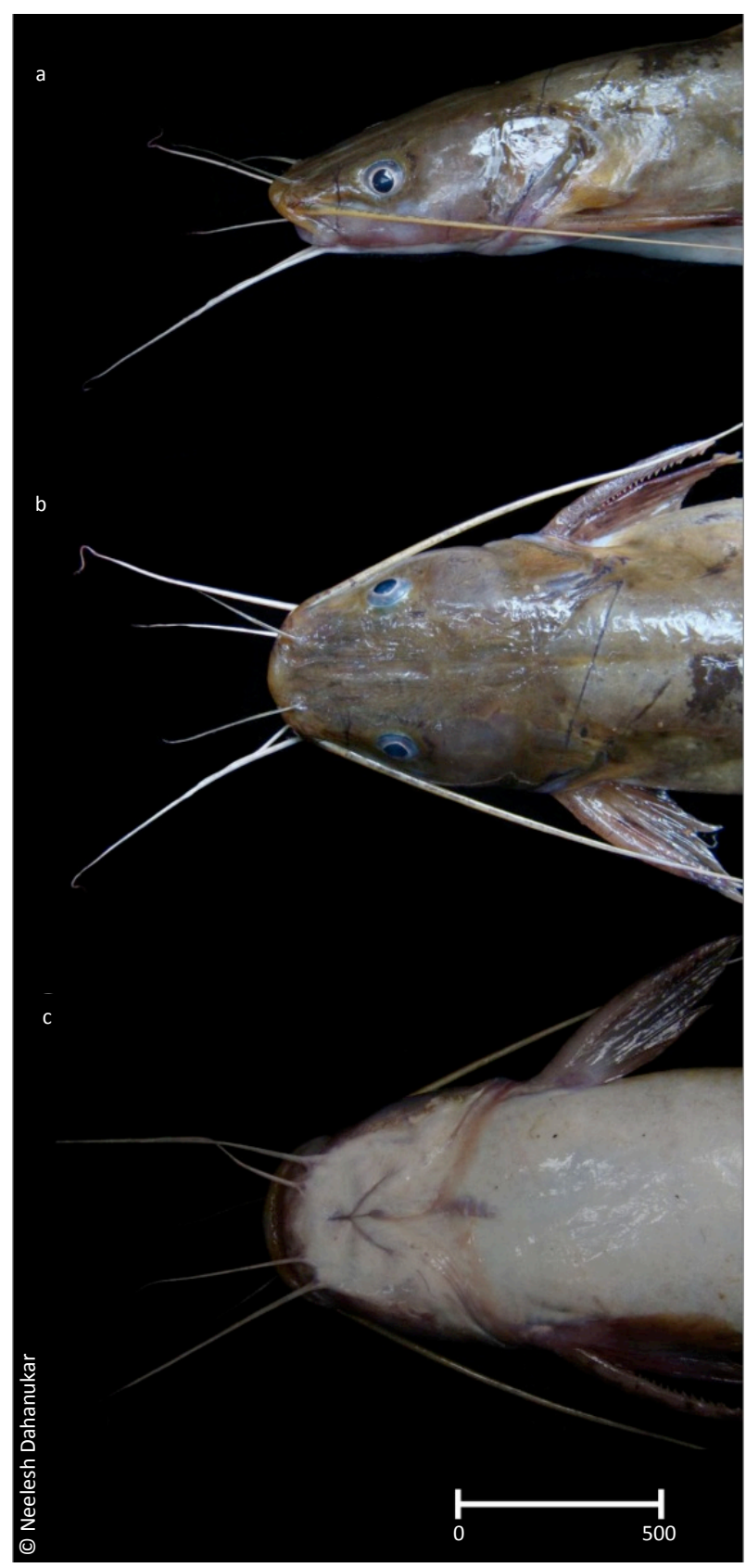

Image 2. Details of (a) lateral, (b) dorsal) and (c) ventral view of head of Hemibagrus punctatus (WILD-12-PIS-026) recorded from Bhavani River.

(Image 6). Unfortunately, specimens could not be collected due to logistical difficulties, and therefore its validity could not be determined. Photographic evidence (Image 6), has led us to tentatively identify the specimen as Hemibagrus cf. punctatus. More surveys are therefore needed in the Bharatapuzha River to confirm the occurrence of this species. Historic and current distribution of $H$. punctatus is shown in Fig. 1.

Hemibagrus punctatus has sometimes been

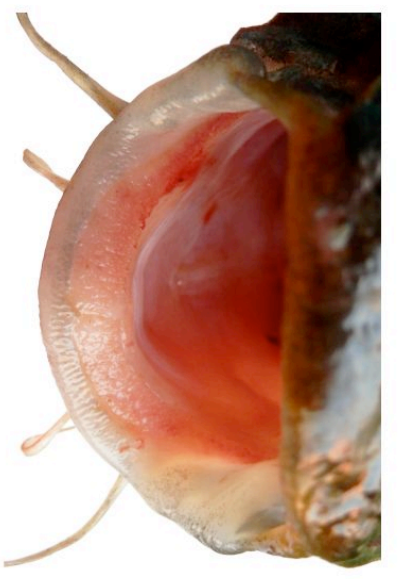

b

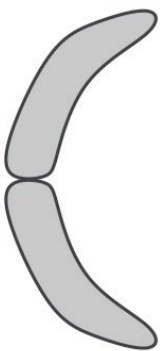

C

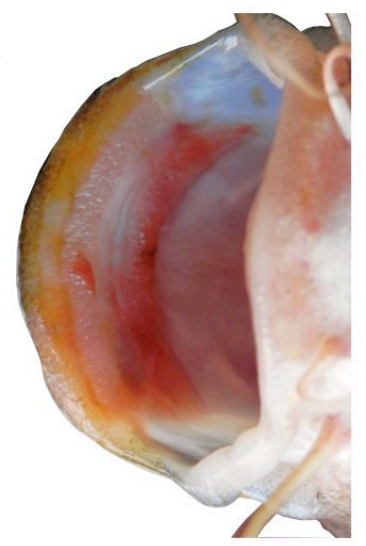

d

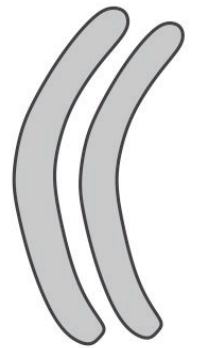

Image 3. Teeth bands on the lower ( $a$ and $b$ ) and upper (c and d) jaw of Hemibagrus punctatus.

confused with $H$. menoda and misidentified (see $\mathrm{Ng}$ \& Ferraris 2000). Although the distribution of $H$. menoda is restricted to the Brahmaputra, Ganges, Mahanadi and Godavari river drainages in India, Nepal and Bangladesh (Ng 2010; Ng \& Ferraris 2000), there are records of this species from the west flowing Pamba and Achankovil rivers in southern Kerala (Kurup et al. 2004; Renjithkumar et al. 2011). However, none of these records are accompanied by voucher specimens, making any validation impossible. Therefore, future studies should also focus on determining the correct identity of the specimens that have been recorded as $H$. menoda from these river systems.

\section{Population}

Members of the genus Hemibagrus are known to be rare, and seldom encountered in local markets ( $\mathrm{Ng} \mathrm{\&}$ Ferraris 2000). Hemibagrus punctatus is the only member within the genus that is threatened and continues to face population declines (see various species accounts 
Table 1. Morphometric data for Hemibagrus punctatus collected during the present study, and data from Ng \& Ferraris (2000) and Ng \& Kottelat (2013).

\begin{tabular}{|c|c|c|c|c|c|c|c|c|}
\hline Characters & $\begin{array}{l}\text { WILD- } \\
\text { PIS-12-026 }\end{array}$ & $\begin{array}{l}\text { CRG-SAC. } \\
2012.12 .1\end{array}$ & $\begin{array}{l}\text { CRG-SAC. } \\
2012.12 .2\end{array}$ & $\begin{array}{l}\text { CRG-SAC. } \\
2012.12 .3\end{array}$ & $\begin{array}{l}\text { Mean }(s d) \\
\quad(n=4)\end{array}$ & $\begin{array}{l}\text { Range } \\
(n=4)\end{array}$ & $\begin{array}{c}\mathrm{Ng} \& \\
\text { Ferraris } \\
(2000) \\
(n=3)\end{array}$ & $\begin{array}{c}\mathrm{Ng} \& \\
\text { Kottelat } \\
(2013) \\
(n=4)\end{array}$ \\
\hline Total length (mm) & 355 & 220 & 216 & 286 & $269(65.56)$ & $216-355$ & & \\
\hline Standard Length $(\mathrm{mm})$ & 270 & 182 & 180 & 232 & $216(43.3)$ & $180-270$ & $120.2-193.1$ & $120.2-193.1$ \\
\hline \multicolumn{9}{|l|}{$\% \mathrm{SL}$} \\
\hline Head Length & 27.3 & 27.4 & 26.9 & 26.5 & $27.0(0.41)$ & $26.5-27.4$ & $28.1-29.6$ & $28.1-29.6$ \\
\hline Head Depth & 12.3 & 13.6 & 13.8 & 13.3 & $13.3(0.67)$ & $12.3-13.8$ & $11.9-14.3$ & $11.9-14.3$ \\
\hline Maximum Head Width & 18.1 & 19.2 & 19.2 & 19.5 & $19.0(0.62)$ & $18.1-19.5$ & $16.4-20.5$ & $16.4-20.5$ \\
\hline Pre Dorsal Length & 39.3 & 40.4 & 39.9 & 38.4 & $39.5(0.86)$ & $38.4-40.4$ & $39.8-42.0$ & $39.8-42.0$ \\
\hline $\begin{array}{l}\text { Anterior border of dorsal fin base } \\
\text { to caudal fin length }\end{array}$ & 62.7 & 63.1 & 64.0 & 64.9 & $63.7(0.98)$ & $62.7-64.9$ & - & - \\
\hline $\begin{array}{l}\text { Posterior border of dorsal fin } \\
\text { base to caudal fin length }\end{array}$ & 47.5 & 46.6 & 49.1 & 50.3 & $48.4(1.65)$ & $46.6-50.3$ & - & - \\
\hline Pre Pectoral Length & 20.0 & 23.4 & 22.7 & 23.5 & $22.4(1.64)$ & $20.0-23.5$ & $26.2-26.6$ & $26.2-26.6$ \\
\hline Pre Pelvic Length & 55.2 & 51.4 & 51.2 & 50.9 & $52.2(2.03)$ & $50.9-55.2$ & $53.3-54.2$ & $53.9-55.7$ \\
\hline Pre Anal Length & 70.9 & 69.8 & 68.4 & 67.6 & $69.2(1.47)$ & $67.6-70.9$ & $71.0-74.2$ & $71.0-74.2$ \\
\hline Pre Anus Length & 63.4 & 58.4 & 56.5 & 58.4 & $59.2(2.96)$ & $56.5-63.4$ & - & - \\
\hline Depth at Dorsal Origin & 16.6 & 17.9 & 17.7 & 16.8 & $17.3(0.65)$ & $16.6-17.9$ & - & - \\
\hline Depth at Anal Origin & 14.3 & 13.3 & 13.7 & 13.0 & $13.6(0.56)$ & $13.0-14.3$ & - & - \\
\hline Width at Dorsal Origin & 15.7 & 16.0 & 15.5 & 14.9 & $15.5(0.46)$ & $14.9-16.0$ & - & - \\
\hline Width at Anal Origin & 10.2 & 9.5 & 10.0 & 9.1 & $9.7(0.5)$ & $9.1-10.2$ & - & - \\
\hline Least Depth of Caudal Peduncle & 9.8 & 8.9 & 8.7 & 9.0 & $9.1(0.48)$ & $8.7-9.8$ & $8.8-9.9$ & $8.8-9.9$ \\
\hline Caudal Peduncle Length & 18.7 & 16.8 & 16.6 & 18.1 & $17.6(1.01)$ & $16.6-18.7$ & $16.1-18.6$ & $16.1-18.6$ \\
\hline Dorsal Fin Length & 21.0 & 24.8 & 24.0 & 25.3 & $23.8(1.93)$ & $21.0-25.3$ & $24.7-27.6$ & $24.7-27.6$ \\
\hline Dorsal Fin Base Length & 15.6 & 16.6 & 15.5 & 17.7 & $16.4(1.03)$ & $15.5-17.7$ & $14.7-17.4$ & $14.7-17.4$ \\
\hline Pectoral Fin Length & 19.5 & 17.3 & 15.7 & 16.2 & $17.2(1.69)$ & $15.7-19.5$ & $18.7-21.1$ & $18.7-21.1$ \\
\hline Pectoral Fin Base Length & 4.5 & 4.6 & 4.5 & 5.2 & $4.7(0.34)$ & $4.5-5.2$ & - & - \\
\hline Pelvic Fin Length & 14.2 & 13.1 & 13.2 & 15.2 & $13.9(0.98)$ & $13.1-15.2$ & $14.9-17.2$ & 14.9-17.2 \\
\hline Anal Fin Length & 15.1 & 19.2 & 18.4 & 19.2 & $18.0(1.95)$ & $15.1-19.2$ & - & - \\
\hline Anal Fin Base Length & 11.3 & 13.7 & 12.3 & 13.3 & $12.7(1.08)$ & $11.3-13.7$ & $11.8-14.3$ & $11.8-14.3$ \\
\hline Dorsal to Adipose Distance & 27.7 & 34.5 & 37.8 & 36.7 & $34.2(4.53)$ & $27.7-37.8$ & $16.3-19.4$ & $16.3-19.4$ \\
\hline Adipose Fin Length & 13.6 & 17.3 & 17.0 & 16.3 & $16.1(1.69)$ & $13.6-17.3$ & - & - \\
\hline Adipose Fin Base Length & 10.7 & 13.2 & 12.3 & 12.8 & $12.3(1.1)$ & $10.7-13.2$ & $10.1-13.2$ & $10.1-13.2$ \\
\hline Adipose Fin Height & 3.5 & 3.4 & 3.1 & 4.1 & $3.5(0.42)$ & $3.1-4.1$ & $3.9-5.4$ & $3.9-5.4$ \\
\hline Post Adipose Distance & 16.2 & 16.1 & 16.6 & 15.2 & $16.0(0.59)$ & $15.2-16.6$ & 16.2 & $14.8-16.2$ \\
\hline Maxillary Barbel Length & 43.0 & 40.6 & 42.6 & 30.0 & $39.1(6.12)$ & $30.0-43.0$ & - & - \\
\hline Nasal Barbel Length & 10.9 & 7.7 & 7.3 & 7.5 & $8.4(1.71)$ & $7.3-10.9$ & - & - \\
\hline Mandibular Barbel Length & 24.7 & 17.0 & 17.2 & 13.1 & $18.0(4.85)$ & $13.1-24.7$ & - & - \\
\hline Inner Mandibular Barbel Length & 15.3 & 10.4 & 9.2 & 8.4 & $10.8(3.09)$ & $8.4-15.3$ & - & - \\
\hline \multicolumn{9}{|l|}{$\% \mathrm{HL}$} \\
\hline Head Depth & 45.0 & 49.5 & 51.1 & 50.1 & $48.9(2.7)$ & $45.0-51.1$ & - & - \\
\hline Maximum Head Width & 66.3 & 70.2 & 71.2 & 73.8 & $70.4(3.11)$ & $66.3-73.8$ & - & - \\
\hline Eye Diameter & 13.2 & 15.7 & 14.2 & 14.4 & $14.4(1.03)$ & $13.2-15.7$ & $13-8-15.7$ & $13-8-15.7$ \\
\hline Snout Length & 35.3 & 39.5 & 40.2 & 41.0 & $39.0(2.54)$ & $35.3-41.0$ & $35.7-38.9$ & $35.7-38.9$ \\
\hline Inter Orbital Length & 35.4 & 35.2 & 33.4 & 33.9 & $34.5(0.98)$ & $33.4-35.4$ & $31.3-32.5$ & $31.3-32.5$ \\
\hline
\end{tabular}




\begin{tabular}{|c|c|c|c|c|c|c|c|c|}
\hline Characters & $\begin{array}{l}\text { WILD- } \\
\text { PIS-12-026 }\end{array}$ & $\begin{array}{l}\text { CRG-SAC. } \\
2012.12 .1\end{array}$ & $\begin{array}{l}\text { CRG-SAC. } \\
2012.12 .2\end{array}$ & $\begin{array}{c}\text { CRG-SAC. } \\
2012.12 .3\end{array}$ & $\begin{array}{c}\text { Mean (sd) } \\
(n=4)\end{array}$ & $\begin{array}{l}\text { Range } \\
(n=4)\end{array}$ & $\begin{array}{c}\mathrm{Ng} \mathrm{\&} \\
\text { Ferraris } \\
(2000) \\
(n=3)\end{array}$ & $\begin{array}{c}\mathrm{Ng} \& \\
\text { Kottelat } \\
(2013) \\
(n=4)\end{array}$ \\
\hline Eye to Nostril Distance & 23.8 & 20.6 & 20.7 & 20.4 & $21.4(1.62)$ & $20.4-23.8$ & - & - \\
\hline Inter Nostral Distance & 17.9 & 18.6 & 19.3 & 20.6 & $19.1(1.15)$ & 17.9-20.6 & - & - \\
\hline Gape Width & 41.7 & 40.5 & 40.8 & 43.9 & $41.7(1.54)$ & $40.5-43.9$ & - & - \\
\hline Post Orbital Length & 52.1 & 48.3 & 48.9 & 51.4 & $50.2(1.86)$ & $48.3-52.1$ & - & - \\
\hline Maxillary Barbel Length & 157.7 & 148.1 & 158.4 & 113.3 & $144.4(21.24)$ & $113.3-158.4$ & $163.2-203.4$ & $163.2-203.4$ \\
\hline Nasal Barbel Length & 39.8 & 28.1 & 27.3 & 28.2 & $30.9(5.98)$ & $27.3-39.8$ & $27.5-40.3$ & $27.5-40.3$ \\
\hline Mandibular Barbel Length & 90.6 & 62.0 & 63.7 & 49.7 & $66.5(17.24)$ & 49.7-90.6 & $68.8-80.2$ & $68.8-80.2$ \\
\hline Inner Mandibular Barbel Length & 56.3 & 37.8 & 34.2 & 31.8 & $40.0(11.13)$ & $31.8-56.3$ & $31.7-45.6$ & $31.7-45.6$ \\
\hline
\end{tabular}

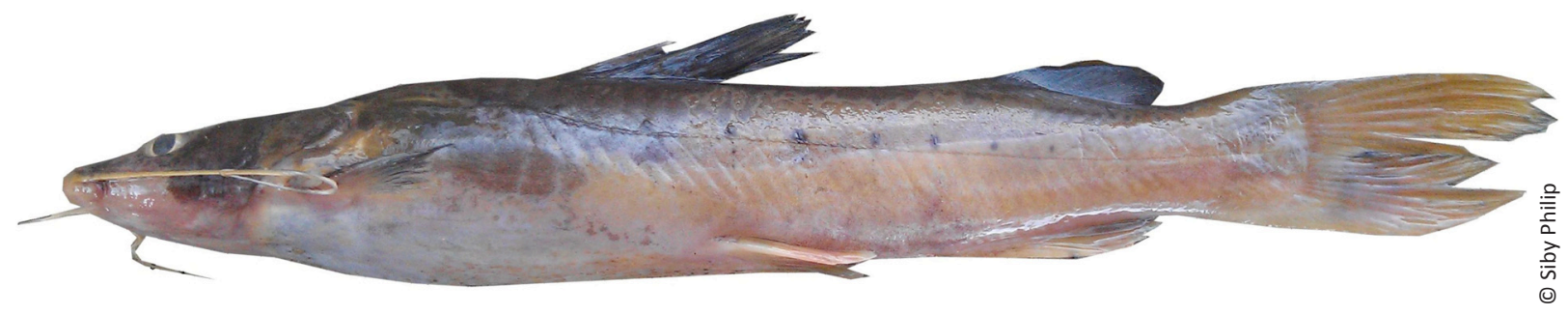

Image 4. Specimen of Hemibagrus punctatus collected from Malavalli, Cauvery River, Karnataka (CRG-SAC-2012.12.1)

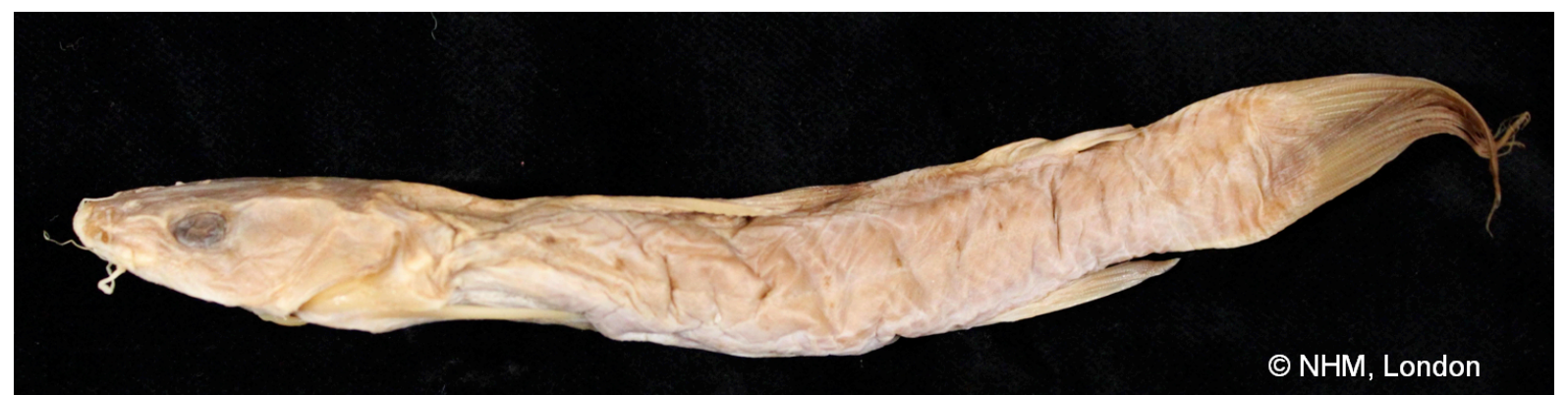

Image 5. Day's material of Hemibagrus punctatus from Bhavani River (BMNH 1868.14:8; 155mm SL). Photograph by Rajeev Raghavan

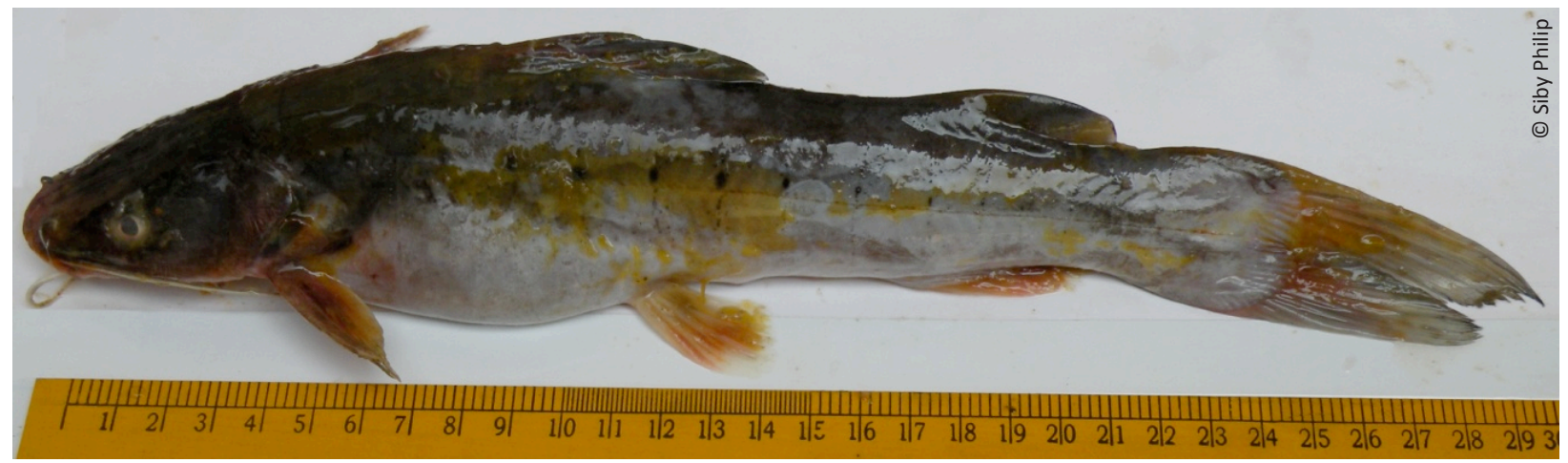

Image 6. Specimen of Hemibagrus cf punctatus recorded from Kanjirapuzha (Bharatapuzha River) in 2008. [Scale in cm]. 
in IUCN Red List of Threatened Species). From an extensive collection of fishes from Cauvery River, Hora (1937) recorded only a single specimen of $H$. punctatus. Similarly, Mukerji (1931) recorded a single specimen (200mm in length) from Bhavani River, Coimbatore District, Tamil Nadu, while Rajan (1955) also recorded only a single specimen (320mm in length) from Moyar River at Mangalapatti, Erode District, Tamil Nadu. The species was also reported to be rare in Ombatta swamp of Mudumalai Wildlife Sanctuary (Manimekalan 1998). The maximum number of individuals of $H$. punctatus that has been recorded is $\sim 50$ in the Cauvery Sangam near Mysore in 1996 (J. Jensen pers. comm 03 December 2012).

In the Kabini River (Wyanad, Kerala), this species has declined drastically in the last decade with not a single specimen being encountered during repeated surveys since the year 2000 (C.P. Shaji \& B.M. Kurup pers. obs. In: Ali \& Raghavan 2011). In Tungabhadra, the species was last recorded in the 1980's (Singit et al. 1987), while the last validated record from Moyar was during 19901992 (see Ali \& Raghavan 2011). Surveys by Johnson \& Arunachalam (2009) (actual surveys conducted in 20012002) in three tributaries of the Cauvery failed to collect $H$. punctatus. Overall populations in the native range were, therefore, thought to have declined close to $100 \%$ in the last 14 years (Ali \& Raghavan 2011). Our record of four specimens caught by local fisherman from the Bhavani and Cauvery rivers in November and December 2012, and local knowledge of fishers in the region suggest that moderate populations of the species are still extant in both the main basin as well as the major tributaries of the Cauvery River and that the fish is not extinct as believed previously (Ali \& Raghavan 2011).

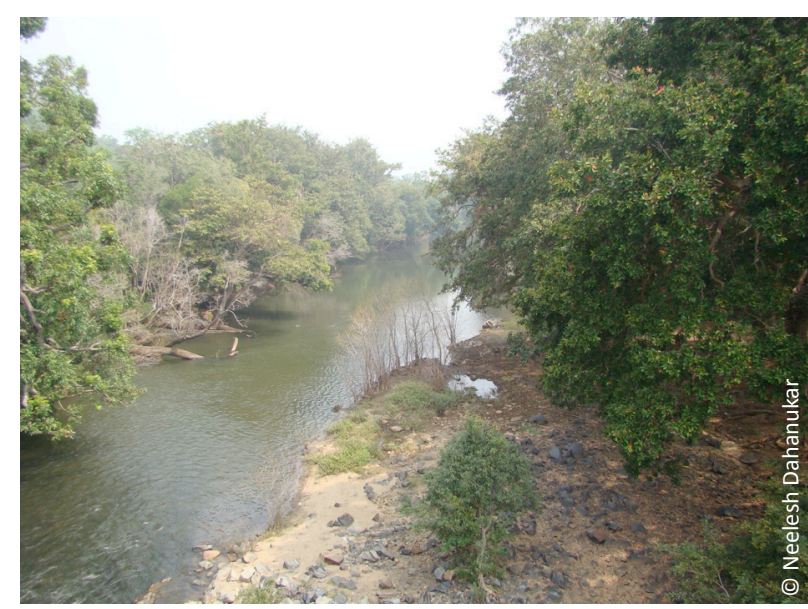

Image 7. Habitat of Hemibagrus punctatus at Athikadavu in Bhavani River.
Our surveys in the various fish landing centers along the Cauvery in Karnataka State, and interactions with local fishers reveal that $H$. punctatus is not 'uncommon' in the area, but represents only a very negligible part of the catch.

\section{Habitat and Ecology}

Hemibagrus punctatus is known to inhabit rapid rivers and streams (Menon 1999), as well as medium and large reservoirs. The location from where the fisherman caught his specimen of $H$. punctatus in Athikadavu, Bhavani was a fast flowing stream with deep pools, and bed rock as the substrate (Image 7). The bank on one side had a thick canopy with several wooden logs submerged in the water, while the other bank had a sandy bed with shrubs. The co-occuring species in the fisherman's catch at Athikadavu were Hypselobarbus dubius, Barbodes carnaticus, Kantaka brevidorsalis and Channa marulius. Although we encountered the fisherman at Malavalli, the catch was obtained from a stream flowing $16 \mathrm{~km}$ east of the town, where the habitat is a fast flowing stream with deep pools and bed rock substrate, with a sandy bed and shrubs on both the shores. The co-occuring species as seen from the catches were Channa marulius, Barbodes carnaticus, Hypselobarbus dubius, Oreochromis mossambicus and $O$. niloticus. The fishermen also revealed that $H$. punctatus occur in the river at Malavalli (Image 8) but are encountered rarely. The other sites from where the specimens of $H$. punctatus were recorded in catches of local fishermen include the Krishna Raja Sagar (KRS) reservoir near Mysore and the stream near the town of Bannur.

Based on the feeding habits of related species

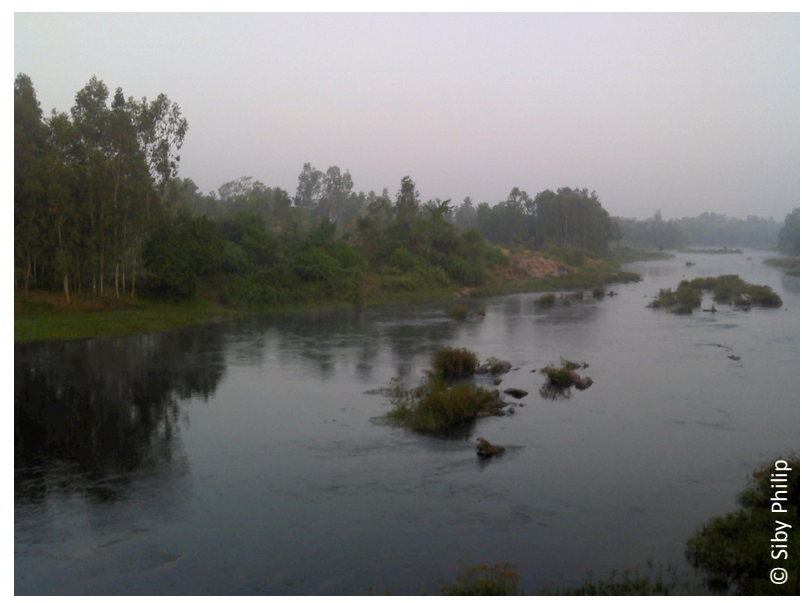

Image 8. Probable habitat of Hemibagrus punctatus near Malavalli in Cauvery River. 
within the genus Hemibagrus (Froese \& Pauly 2012), $H$. punctatus is most likely to be a carni-omnivore. Rajan (1955) recorded adult specimen (103mm in length) and a severed head (25mm long) of Garra stenorhynchus inside the gut of $H$. punctatus (320mm in length) collected from the headwaters of the Bhavani River.

Hemibagrus punctatus is known to attain a maximum size of $450 \mathrm{~mm}$ TL (Day 1889; Menon 1999). Records of $H$. punctatus from the Tungabhadra Reservoir with sizes of 25-35 kg (and up to 120kg) (Sugunan 1995) are misidentifications and represent $H$. maydelli, which $\mathrm{Ng}$ \& Kottelat (2013) consider as one of the largest known species within this genus.

\section{Phylogenetic position}

The taxonomy of Hemibagrus is known to be confusing with the validity of many nominal species still unclear (Ng \& Kottelat 2013). These authors defined eight 'species groups' of Hemibagrus based on morphological characteristics. Here, using mitochondrial cox1 gene, we show that $H$. punctatus and $H$. menoda are indeed sibling species belonging to the same species group as suggested by $\mathrm{Ng} \&$ Kottelat (2013) with a $4.2 \%$ genetic distance separating them (Fig. 2).

\section{Threats}

The Cauvery and its tributaries from where $\mathrm{H}$. punctatus has been recorded are subjected to several on-going threats including pollution, construction of barrages and indiscriminate fishing (Dahanukar et al. 2011). Athikadavu, from where we recorded one of our specimens is relatively free of threats barring gill net fishery by the local communities for sustenance.

\section{Conservation actions}

No species level conservation plans are currently in place. There is a need for organized surveys throughout the known range of $H$. punctatus to determine the

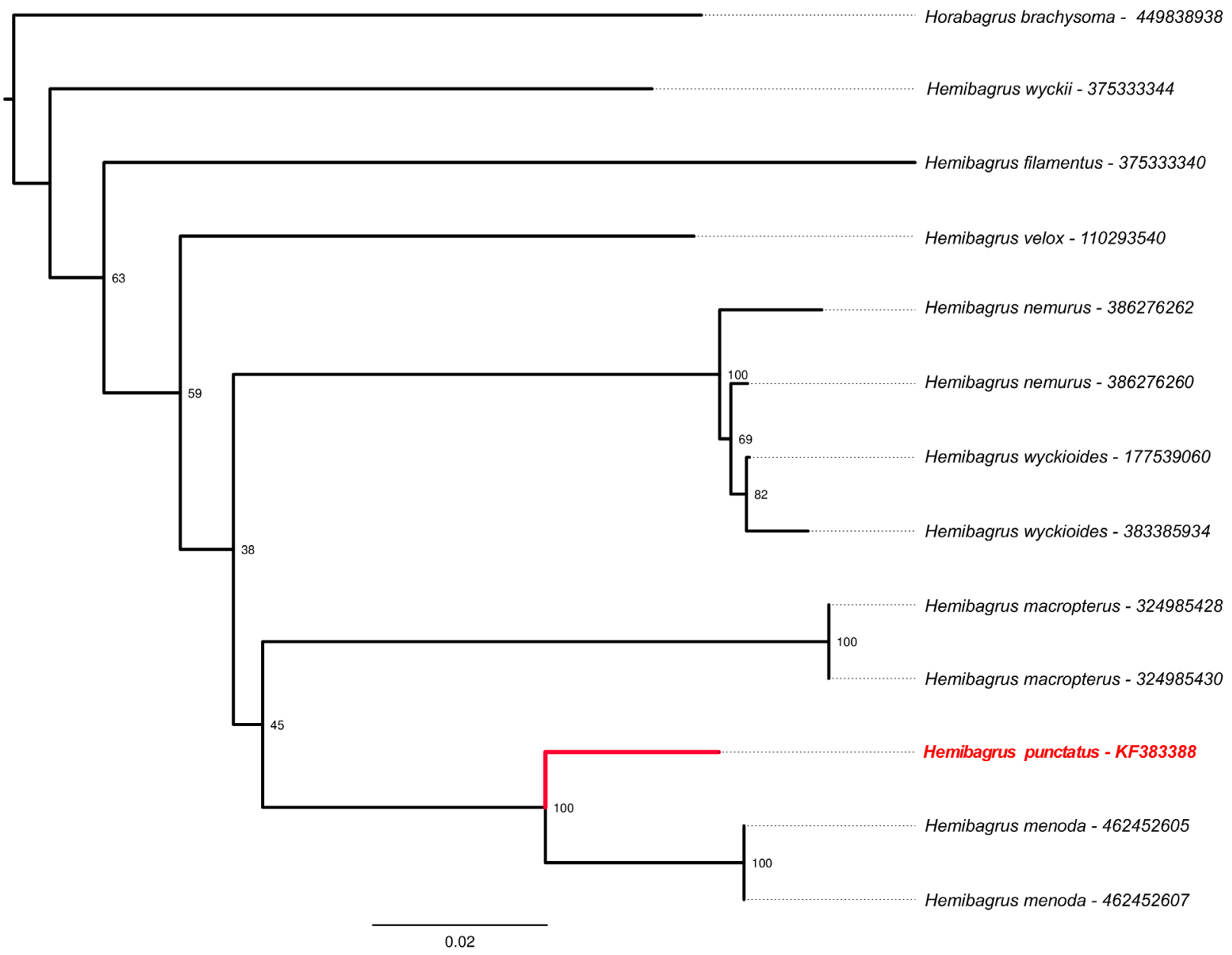

Figure 2. Neighbor Joining phylogenetic tree based on observed distances of cytochrome oxidase subunit 1 (cox1) gene sequences of different Hemibagrus species showing the phylogenetic position of Hemibagrus punctatus. 
current distribution and population status of this species. We are currently carrying out such surveys in the Cauvery and its tributaries including Bhavani and Kabini as part of a project to determine the status of missing fishes of Western Ghats. In addition, there is a need to undertake detailed taxonomic studies to clear the ambiguities related to the identity of specimens that have been recorded as $H$. punctatus (and $H$. menoda) from many west flowing rivers of Kerala. Local Ecological Knowledge surveys (see Kanagavel \& Raghavan 2012) could also help gather important information on the natural history of the species in its native range.

\section{IUCN Red List Assessment}

Current status: Critically Endangered (CR) A2ac (Raghavan \& Ali 2011).

Proposed status: Vulnerable (VU) A2ace, B2ab(iiii)

Justification for the proposed status: Population decline of $\sim 100 \%$ due to habitat loss and several other threats, which are not yet clearly understood, were suggested by researchers after carrying out comprehensive surveys in its native range (see Raghavan \& Ali 2011). While the species may have been extirpated from certain locations, surveys carried out after this assessment have now led to the collection of four specimens from multiple sites in the River Cauvery. However, except for these locations (Athikadavu, Krishnaraja Sagar Dam, Bannur and Malavalli), there are no validated records and voucher specimens of $H$. punctatus since the late 1990s. Although, the local knowledge of fishers indicate that moderate populations of $H$. punctatus exist in the Cauvery, out of the current seven confirmed locations where the species is currently known from, in at least three locations it has been suggested that the population of the species has declined close to 100 percent (Raghavan \& Ali 2011). Even if we consider that the population in the remaining four sites is stable, the average population decline is still more than or equal to $30 \%$. Further, the habitats that are likely to harbour $H$. punctatus in these regions are currently threatened as a result of pollution and dams. The estimated area of occupancy (AOO) is not more than $2000 \mathrm{~km}$ because of very fragmented and restricted distribution of this rare species. Further, the fragmented populations are likely to fall under not more than 10 locations based on the on-going threats to the habitat and populations as mentioned earlier. Therefore, Hemibagrus punctatus needs to be categorized as a 'Vulnerable' species. However, it is advised that further studies on the distribution and population status of this species should be carried out along with detailed taxonomic studies to verify the records of the species from the west flowing rivers of Kerala, and the Krishna River system.

\section{REFERENCES}

Altschul, S.F., W. Gish, W. Miller, E.W. Myers, \& D.J. Lipman (1990). Basic local alignment search tool. Journal of Molecular Biology 215(3): 403410; http://dx.doi.org/10.1016/S0022-2836(05)80360-2

Barman, R.P. (1993). Pisces: Freshwater Fishes. pp 89-334. In: State Fauna Series 5: Fauna of Arunachal Pradesh. Part 1. Ghosh, A.K (ed). Zoological Survey of India, Calcutta.

Biju, C.R. (2005). Habitat and Distribution of Hillstream Fishes of Northern Kerala (north of Palghat Gap). PhD Thesis, Mahatma Gandhi University, Kottayam, India.

Dahanukar, N., R. Raut \& A. Bhat (2004). Distribution, endemism and threat status of freshwater fishes in the Western Ghats of India. Journa of Biogeography 31(1): 123-136; http://www.dx.doi.org/10.1046/ j.0305-0270.2003.01016.x

Dahanukar, N., R. Raghavan, A. Ali, R. Abraham \& C.P. Shaji (2011). The status and distribution of freshwater fishes of the Western Ghats. pp 21-48. In: Molur, S., K.G. Smith, B.A. Daniel \& W.R.T. Darwall (compilers). The Status of Freshwater Biodiversity in the Western Ghats. International Union for Conservation of Nature (IUCN) Gland, Switzerland \& Zoo Outreach Organization (ZOO) Coimbatore, India, $116 p$

Day, F. (1867). On the fishes of the Neilgherry Hills and rivers around their bases. Proceedings of the Zoological Society of London 1867 (pt 2): 281-302.

Day, F. (1877). The fishes of India; being a natural history of the fishes known to inhabit the seas and fresh waters of India, Burma, and Ceylon. Part 3: 369-552, Pls. 79-138.

Day, F. (1878). The fishes of India; being a natural history of the fishes known to inhabit the seas and fresh waters of India, Burma, and Ceylon. Part 4: i-xx + 553-779, Pls. 139-195.

Day, F. (1889). Fishes. In: W. T. Blanford (ed.) The Fauna of British India, including Ceylon and Burma. Taylor \& Francis, London. v. 1: i-xviii + 1-548.

Easa, P.S. \& S.C. Basha (1995). A survey of the habitat and distribution of stream fishes in the Kerala part of Nilgiri Biosphere Reserve. Kerala Fisheries Research Institute Research Report No. 104.

Easa, P.S. \& C.P. Shaji (1997). Freshwater fish diversity in Kerala part of the Nilgiri Biosphere Reserve. Current Science 73(2): 180-182.

Easa, P.S. \& C.P. Shaji (2003). Biodiversity Documentation for Kerala. Part 8. Freshwater Fishes. Kerala Forest Research Institute Handbook No $17,127 p$.

Edgar, R.C. (2004). MUSCLE: multiple sequence alignment with high accuracy and high throughput. Nucleic Acids Research 32: 1792-1797; http://dx.doi.org/10.1093/nar/gkh340

Ferraris, C.J., Jr. (2007). Checklist of catfishes, recent and fossil (Osteichthyes: Siluriformes), and catalogue of siluriform primary types. Zootaxa 1418: 1-628

Froese, R. \& D. Pauly (eds). (2012). FishBase. World Wide Web Electronic Publication. <www.fishbase.org>, Version (10/2012). Downloaded on 01 December 2012.

Gouy, M., S. Guindon \& O. Gascuel (2010). SeaView version 4: a multiplatform graphical user interface for sequence alignment and phylogenetic tree building. Molecular Biology and Evolution 27(2): 221-224; http://dx.doi.org/10.1093/molbev/msp259

Hora, S.L. (1937). On three collections of fish from Mysore and Coorg, South India. Records of the Indian Museum 39: 5-28.

Jayaram, K.C. (1954). Siluroid fishes of India, Burma and Ceylon. XIV Fishes of the genus Mystus Scopoli. Records of the Indian Museum (Calcutta) 51(4): 527-558, PI. 1.

Jayaram, K.C. (1977). Aid to identification of siluroid fishes of India, Burma, Sri Lanka, Pakistan and Bangladesh. 1. Bagridae. Records of 
the Zoological Survey of India. Miscellaneous Publication, Occasional Paper No. 8: 1-41.

Jayaram, K.C. (1981). The freshwater fishes of India, Pakistan, Bangladesh, Burma and Sri Lanka - a handbook. Zoological Survey of India. i-xxii + 1-475, Pls. 1-13.

Jayaram, K.C. (2006). Catfishes of India. Narendra Publishing House, Delhi. i-xxii +1-383, Pls. 111.

Jerdon, T.C. (1849). On the fresh-water fishes of southern India. (Continued from p. 149.). Madras Journal of Literature and Science 15 (2): 302-346.

Johnson, J. \& M. Arunachalam (2009). Diversity, distribution and assemblage structure of fishes in streams of southern Western Ghats, India. Journal of Threatened Taxa 1(10): 507-513; http://dx.doi. org/10.11609/JoTT.o2146.507-13

Kanagavel, A. \& R. Raghavan (2012). Local knowledge and threatened Chelonians: Informing the status of Cochin Forest Cane Turtle (Vijayachelys silvatica) and Travancore Tortoise (Indotestudo travancorica) in the Anamalai Hills of Western Ghats. Journal of Threatened Taxa 4(13): 3173-3182; http://dx.doi.org/10.11609/JoTT. o3003.3173-82

Kurup, B.M., K.V. Radhakrishnan \& T.G. Manojkumar (2004). Biodiversity Status of Fishes Inhabiting Rivers of Kerala (South India) With Special Reference to Endemism, Threats and Conservation Measures. In: Welcomme, R.L \& T. Petr (eds.). Proceedings of the Second International Symposium on the Management of Large Rivers for Fisheries 2: 163182. FAO/MRC, Cambodia.

Madhyastha, M.N. \& S. Murugan (1993). Socio-economic status of fisherfolk in relation to fish and fisheries of Hemavathy Reservoir. Indian Journal of Fisheries 40(4): 267-269.

Manimekalan, A. (1998). The fishes of Mudumalai Wildlife Sanctuary, Tamil Nadu, South India. Journal of the Bombay Natural History Society 95(3): 431-443.

Menon, A.G.K. (1999). Check list - fresh water fishes of India. Records of the Zoological Survey of India. Miscellaneous Publication, Occasional Paper No. 175: i-xxviii + 1-366.

Mo, T.-P. (1991). Anatomy and Systematics of Bagridae (Teleostei) and Siluroid Phylogeny. Koeltz Scientific Books. Koenigstein, Germany, vii+216pp+63 pages of figures.

Mukerji, D.D. (1931). On a small collection of fish from the Bhavan River (S. India). Journal of the Bombay Natural History Society 35(1): 162-171.
Ng, H.H. (2010). Hemibagrus menoda. In: IUCN 2012. IUCN Red List of Threatened Species. Version 2012.2. <www.iucnredlist.org>. Downloaded on 03 December 2012.

Ng, H.H. \& M. Kottelat (2013). Revision of the Asian catfish genus Hemibagrus Bleeker 1862 (Teleostei: Siluriformes: Bagridae). The Raffles Bulletin of Zoology 61(1): 205-291.

Ng, H.H. \& C.J. Ferraris Jr. (2000). A review of the genus Hemibagrus in southern Asia, with descriptions of two new species. Proceedings of the California Academy of Sciences 52(11): 125-142.

Raghavan, R. \& A. Ali (2011). Hemibagrus punctatus. In: IUCN 2012. IUCN Red List of Threatened Species. Version 2012.2. <www.iucnredlist. org>. Downloaded on 01 December 2012.

Rajan, S. (1955) Notes on a collection of fish from the headwaters of the Bhavani River, South India. Journal of the Bombay Natural History Society 53: 44-48.

Rajan, S. (1963). Ecology of the fishes of rivers Pykara and Moyar (Nilgiris), S. India. Proceedings of the Indian Academy of Sciences B 58; 291-293.

Rao, C.R.N. \& B.R. Seshachar (1927). Notes on the fresh water fish of Mysore. Half Yearly Journal of Mysore University 1: 115-143.

Renjithkumar, C.R., M. Harikrishnan \& B.M. Kurup (2011). Exploited fisheries resources of the Pampa River, Kerala, India. Indian Journal of Fisheries 58(3): 13-22.

Shaji, C.P. \& P.S. Easa (1995). Freshwater fish diversity in Wayanad, Kerala, South India. Journal of the Zoological Society of Kerala 5(1\&2): 30-36.

Singit, G.S., P.R. Reddy \& H.V. Krishnamaraju (1987). Post impoundment changes and effects of conflicting uses on fisheries of Tungabhadra reservoir India. In: De Silva, S.S. (ed.), Reservoir Fishery Management and Development in Asia, 14pp.

Sugunan, V.V. (1995). Reservoir Fisheries of India. FAO Fisheries Technical Paper No. 345. Rome, 423pp.

Talwar, P.K. \& A.G. Jhingran (1991). Inland Fishes of India and Adjacent Countries. Oxford \& IBH Publishing Co. New Delhi. 2 Vols., 1158pp.

Thomas, R.K., M.J. George \& C.R. Biju (2002). Freshwater fishes of Southern Kerala with notes on the distribution of endemic and endangered species. Journal of the Bombay Natural History Society 99(1): 47-53.

Ward, R.D., T.S. Zemlak, B.H. Innes, P.R. Last \& P.D. Hebert (2005). DNA barcoding Australia's fish species. Philosophical Transactions of the Royal Society B: Biological Sciences 360(1462): 1847-1857; http:// dx.doi.org/10.1098/rstb.2005.1716

Appendix 1.

Morphometry

Morphometric and meristic data were recorded following Ng \& Ferraris (2000). Measurements were taken point to point using dial calipers to the nearest $0.1 \mathrm{~mm}$. Measurements of body parts are reported as percentage of standard length (SL) and measurements of subunits of head are reported as percentage of head length $(\mathrm{HL})$

\section{DNA isolation and molecular phylogeny}

Muscle tissue was harvested from one fresh specimen (WILD-12-PIS-026) and was preserved in absolute ethanol. The tissue was digested at $60^{\circ} \mathrm{C}$ for two hours using the STE buffer $(0.1 \mathrm{M} \mathrm{NaCl}, 0.05 \mathrm{M}$ Tris- $\mathrm{HCl}, 0.01 \mathrm{M}$ EDTA, $1 \%$ SDS) with $15 \mu \mathrm{l}$ Proteinase $\mathrm{K}$ (20mg/ml) per 500ml of STE buffer. DNA was extracted using conventional phenol-chloroform method and re-suspended in nuclease free water. Polymerase chain reaction was performed to amplify mitochondrial cytochrome oxidase subunit I (cox1) gene, using the forward primer Fish R1 (5'- TCAACCAACCACAAAGACATTGGCAC-3') and reverse primer Fish R1 (5'- TAGACTTCTGGGTGGCCAAAGAATCA -3') (Ward et al. 2005). PCR reaction was performed in a $25 \mu l$ reaction volume containing $5 \mu \mathrm{l}$ of template DNA ( $200 \mathrm{ng}), 2.5 \mu \mathrm{l}$ of $10 \mathrm{X}$ reaction buffer ( $100 \mathrm{mM}$ Tris $\mathrm{pH} 9.0,500 \mathrm{mM} \mathrm{KCl}, 15 \mathrm{mM} \mathrm{MgCl} 2,0.1 \% \mathrm{Gelatin}), 2 \mu \mathrm{l}$ of $25 \mathrm{mM} \mathrm{MgCl} 2,1 \mu \mathrm{l}$ of $10 \mathrm{mM}$ dNTPs, $1 \mu \mathrm{l}$ of each primer, $1 \mu \mathrm{l}$ Taq polymerase and $16.5 \mu \mathrm{l}$ nuclease free water. The thermal profile was 10 minutes at $95^{\circ} \mathrm{C}$, and 35 cycles of 1 minute at $94^{\circ} \mathrm{C}, 1$ minute at $54^{\circ} \mathrm{C}$ and 2 min at $72^{\circ} \mathrm{C}$, followed by extension of 10 min at $72^{\circ} \mathrm{C}$. Amplified DNA fragments were purified using the 'Promega Wizard Gel and PCR clean up' system and sequenced. The purified PCR products were sequenced using ABI prism 3730 sequencer (Applied Biosystems, USA) and Big dye terminator sequencing kit (ABI Prism, USA).

BLAST tool (Altschul et al. 1990) was used to analyze the integrity of the sequence. The sequence was submitted to NCBI GenBank and accession number for this sequence is KF383388. We retrieved additional sequences for other related species from NCBI GeneBank database (http://www. ncbi.nlm.nih.gov/). GenBank GI record numbers for the sequences used for the analysis are provided in Figure 2. Sequences were aligned using MUSCLE (Edgar 2004). A neighbor joining phylogeny with observed distances was built using SeaView (Gouy et al. 2010). 